\title{
A Four-tier Diagnostic Instrument: An Analysis of Elementary Student Misconceptions in Science Topic
}

\author{
Kartimi ${ }^{1 *}$, Yunita ${ }^{2}$, Fitri Nurzakiah Fuadi3 ${ }^{3}$ Istiqomah Addiin ${ }^{4}$ \\ 1,2, Tadris Biologi, IAIN Syekh Nurjati, Cirebon, Indonesia \\ ${ }^{3}$ Pendidikan Dasar, Universitas Pendidikan Indonesia, Bandung, Indonesia \\ ${ }^{4}$ Pendidikan Sains, Universitas Sebelas Maret, Surakarta, Indonesia
}

\section{DOI: $10.29303 /$ ippipa.v7iSpeciallssue.1022}

\section{Article Info}

Received: October 10 $10^{\text {th }}, 2021$

Revised: November 17th, 2021

Accepted: November 23rd, 2021

\begin{abstract}
Learning science in elementary schools encourages students to understand the natural environment more deeply, rationally, and scientifically. However, often the scientific concepts they believe about science topics are not in accordance with the scientific concepts they should be. This misconception is difficult for teachers to diagnose. Special instruments to identify and analyze students' misconceptions are needed. Therefore, this research aims to analyze the misconceptions of elementary school students on the topic of energy using a four-tier diagnostic instrument. The purposed-designed survey method was used in this study. The data were analyzed quantitatively and qualitatively. The participants in this study were 20 fourth grade students in an elementary school in Ciamis Regency. A total of 6 questions in the form of a four-tier diagnostic instrument were used to determine the level of students' conceptions. The results showed that the students have misconceptions about the concept of energy. This can be seen from the average percentage of students' misconceptions of $66.67 \%$. This research is expected to contribute to alternative ways to identify and analyze students' misconceptions using the four-tier diagnostic instrument. In addition, it can be used as a reference for teachers and researchers related to the problem of misconceptions of science in elementary school students.
\end{abstract}

Keywords: elementary students; energy concept; four-tier diagnostic instrument; student misconception.

Citation: Kartimi, K., Yunita, Y., Fuadi, F. N. ., \& Addiin, I. (2021). A Four-tier Diagnostic Instrument: An Analysis of Elementary Student Misconceptions in Science Topic. Jurnal Penelitian Pendidikan IPA, 7(SpecialIssue), 61-68. https://doi.org/10.29303/jppipa.v7iSpecialIssue.1022

\section{Introduction}

Science plays an essential role in today's and future global society because science helps humans develop thinking methods and technology both in daily life and in the industry (Shidiq \& Yamtinah, 2019; Yuenyong \& Yuenyong, 2021). Another benefit is that science education encourages students to understand the natural environment more deeply, rationally, and scientifically (Astiti, Ibrahim, \& Hariyono, 2020). However, in the learning process, each student's understanding of a science concept is often different. This difference occurs because each student has a view or conception of the physical world based on everyday experiences (Fuadi, Sopandi, \& Sujana, 2021; Pine, Messer, \& John, 2001). The scientific concepts they believe about the world around them are often not following scientific concepts; this is known as a misconception (Alwan, 2011; Karpudewan, Ahmad, \& Chandrasegaran, 2017). Misconceptions are individual knowledge obtained from learning experiences or informal events that are not relevant to the scientific concept (Laeli, Gunarhadi, \& Muzzazinah, 2020; Soeharto, 2021).

The misconceptions experienced by students will affect their understanding of various natural phenomena. Misconceptions will also have an impact on the process and learning outcomes (Suparno, 2013).

\footnotetext{
*Email: kartimi.iain@gmail.com
} 
Students who have a conception following the truth of science will find it easy to build their knowledge. Meanwhile, students who have a misconception of science will have difficulty in learning. This difficulty is very reasonable because in studying science, every concept is related. When a misconception or misunderstanding occurs in one concept, it is feared that the misconception will continue in other science concepts. In addition, previous studies have shown that students' misconceptions tend to be resistant and difficult to convert to scientific concepts (Bayuni, Sopandi, \& Sujana, 2018; Hermita et al., 2017). Thus, problems regarding misconceptions must be immediately identified and addressed to achieve scientific concepts and meaningful learning (Baryam, Samsudin, Suhandi, Rusdiana, \& Kaniawati, 2017; Cepni, 2009).

Some topics in science learning are abstract and difficult to understand. Energy topic is one of the topics of common misconceptions in the articles reviewed (Laeli et al., 2020; Soeharto, Csapó, Sarimanah, Dewi, \& Sabri, 2019). The concept of energy is considered difficult because the material is abstract and mathematical (Millar, 2005). If misconceptions about energy are not immediately identified and corrected at the beginning of students' learning, they will carry these misconceptions to the upper class. This certainly interferes with the quality and quantity of good science learning outcomes for students. Therefore, a teacher needs to identify and analyze the existence of misconceptions in students' minds to prevent further effects on the following science concept.

There are several methods used to identify the emergence of misconceptions in learning. Diagnostic tests are usually used as a tool to identify students' misconceptions (Astiti et al., 2020; Rohmanasari \& Ermawati, 2020). Such as Two-tier, Three-tier, Four-tier and Five-tier diagnostic instruments (Bayuni et al., 2018; Moon, Zotos, Finkenstaedt-Quinn, Gere, \& Shultz, 2018; Shidiq, Masykuri, \& Susanti, 2014, 2015; Yang \& Lin, 2015). This type of test has been widely used at various levels of education and subjects such as the two-tier test to identify primary students' understanding of acids and bases (Bayrak, 2013), the three-tier test to identify misconceptions on the topic of human reproduction (Hasyim, Suwono, \& Susilo, 2018), and the use of four-tier tests to identify science misconceptions in junior high school students (Caleon \& Subramaniam, 2010).

However, the four-tier diagnostic test is a method that is considered more capable of providing a clear description of students' misconceptions. It is supported by the development of four-tier diagnostic tests that have been widely conducted (Yang \& Lin, 2015). This test provides a comparison of decisions on the choice of concepts and the choice of accompanying reasons that can detect a lack of knowledge based on possible student confidence ratings (Gurel, Eryilmaz, \& McDermott, 2017). Therefore, this research aims to analyze the misconceptions of elementary school students on the topic of energy using a four-tier diagnostic instrument. This research is expected to contribute to alternative ways to identify and analyze students' misconceptions using the four-tier diagnostic instrument. In addition, it can be used as a reference for teachers and researchers related to the problem of misconceptions of science in elementary school students.

\section{Method}

The purpose-designed survey method was used in this study. The research flow design showed in Figure 1 . The data were analyzed quantitatively and qualitatively. This method describes in detail the level of understanding of students' concepts based on the results of diagnostic tests. The participants of this study consisted of 20 public elementary school students in Ciamis. All students are from the fourth grade of elementary school. A total of 6 questions in the form of a four-tier diagnostic instrument were used to determine the level of students' conceptions. The research instrument used is adopted from Fuadi et al., 2021. An example of a four-tier diagnostic instrument is presented in Figure 2.

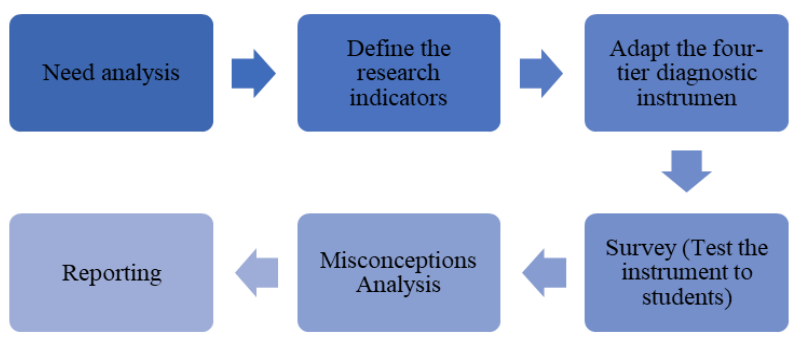

Figure 1. The research flow design

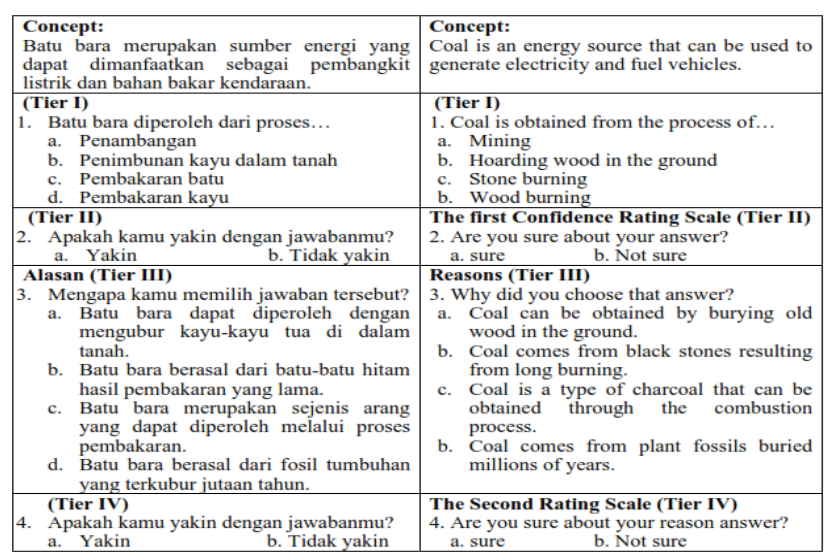

Figure 2. Example of a four-tier diagnostic instrument adopted from Fuadi, Sopandi, \& Sujana (2021) 
The four-tier diagnostic instrument used is in the form of multiple-choice. Investigations conducted through multiple choice with reasons can help in analyzing problems based on certain concepts (Wijayanti, Raharjo, Saputro, \& Mulyani, 2018). There are four multiple-choice formats on the diagnostic test used, namely, tier one related to the concept choice; tier two related to the level of student confidence in the answer choices at tier one, tier three related to the choice of reasons that are in accordance with the concept at tier one, and tier four related to the level of students' confidence in the choice of reasons at tier three. Analysis of students' level of conception is based on the pattern of students' answers. Each student's answer will be determined based on the students' pattern of answers for each level. The results of the combination of student answers can be seen in Table 1 .

Table 1. Categories of Student Concepts Based on Answer Patterns

\begin{tabular}{lllll}
\hline Category & Tier One & Tier two & Tier Three & Tier four \\
\hline Understand Concept (PK) & True & Confident & True & Confident \\
Don't Understand Concept (BK) & True & Confident & True & Not confident \\
& True & Confident & False & Not confident \\
& True & Not confident & True & Confident \\
& True & Not confident & True & Not confident \\
& True & Not confident & False & Not confident \\
& False & Confident & True & Not confident \\
& False & Confident & False & Not confident \\
& False & Not confident & True & Not confident \\
Misconception $(\mathrm{M})$ & False & Not confident & False & Confident \\
& True & Confident & False & Confident \\
& True & Not confident & False & Confident \\
Error $(\mathrm{E})$ & False & Confident & False & Confident \\
& False & Not confident & True & Confident \\
\hline
\end{tabular}

Source: (Hermita et al., 2017)

\section{Result and Discussion}

The level of conception in science learning analyzed in this study is related to energy in the fourth grade of elementary school. The fundamental competencies used are identifying various energy sources, changing forms of energy, and alternative energy sources (wind, water, solar, geothermal, organic fuels, and nuclear) in everyday life. The results of the analysis of the percentage distribution of students' conception levels consisting of understanding concepts, not understanding concepts, errors and misconceptions can be seen in Figure 3.

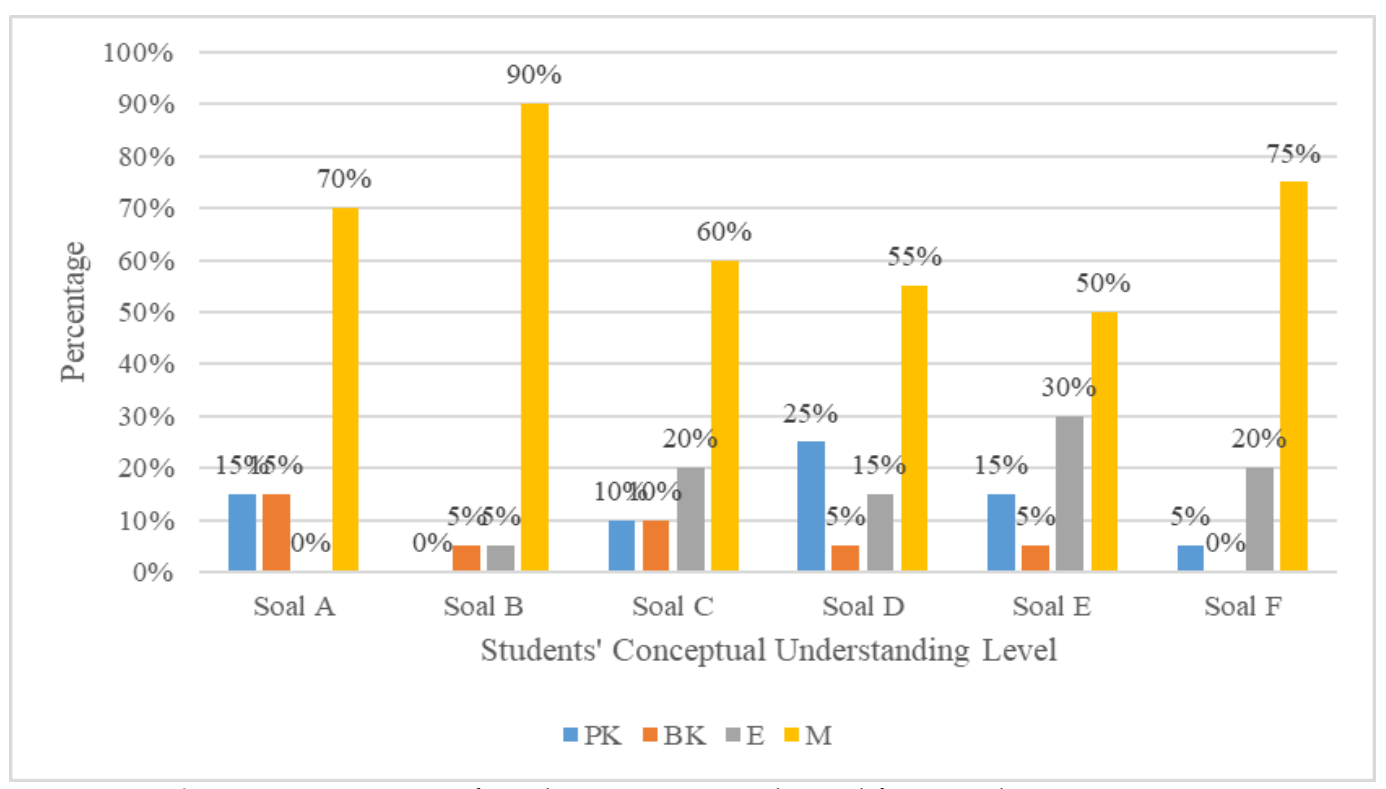

Figure 3. Percentage of Students' Conceptual Level from Each Item 
Students do not come to class without empty minds but come with rich knowledge of their physical world based on their daily experiences (Pine et al., 2001). That way, every student has a conception of science before receiving lessons at school (Yamtinah et al., 2019). Analysis of students' concepts with this fourtier diagnostic instrument can be helpful for teachers to identify misconceptions that occur. The results of this identification can be used to improve the learning process so that students have the proper conceptual knowledge (Gomez-Zwiep, 2008). The advantages of the four-tier diagnostic instrument are (1) it can distinguish the level of confidence in the answers and the level of belief in the reasons chosen by students so that they can dig deeper into students' understanding of concepts, (2) can diagnose misconceptions experienced by students, (3) can determine parts of the material that require more emphasis, (4) can plan better learning process to reduce students' misconceptions (Amin, Wiendartun, \& Samsudin, 2016).

Figure 3 shows that the level of misconception dominates all students' answers in each item. The highest level of misconception appears in question B about explaining the process to obtain non-renewable energy sources. The misconception is when students understand the wrong concept in terms of labels, definitions, attributes, examples, and values (Astiti et al., 2020). So it will be very vulnerable to confusion and multiple interpretations if incorrect concepts are associated with other concepts in a piece of information. Students are categorized as having misconceptions when students choose the answer at the first level, and the reason at the third level is wrong, but students choose to believe in the second and fourth levels (Gurel et al., 2017). Although the level of misconception dominates, there are still students who already have scientific conceptions on indicators of alternative energy use, ways to save fuel, sources of electricity, changes and processes for changing forms of energy. Another level that appears with a percentage below $35 \%$ is not understanding the concept and errors. The level of not understanding this concept can arise because of the lack of information that students have in drawing the correct conclusion to a concept. Several studies reveal that students do not understand concepts yet can be the basis for misconceptions (Caleon \& Subramaniam, 2010; Gurel, Eryilmaz, \& McDermott, 2015)

Concepts that are believed by students who experience misconceptions are often referred to as alternative concepts. The alternative concepts that students in each question number most choose are presented in Table 2.

Table 2. Student Alternative Concepts

\begin{tabular}{|c|c|c|c|}
\hline Code & Indicator & Alternative Concept & Alternative Reason \\
\hline Question A & $\begin{array}{l}\text { Use of alternative energy } \\
\text { sources }\end{array}$ & $\begin{array}{l}\text { Wind energy sources can be used } \\
\text { as an alternative energy source to } \\
\text { replace vehicle fuel. }\end{array}$ & $\begin{array}{l}\text { The energy blows at any time and can } \\
\text { be accommodated to move the vehicle. }\end{array}$ \\
\hline Question B & $\begin{array}{l}\text { The process of obtaining } \\
\text { non-renewable energy } \\
\text { sources. }\end{array}$ & $\begin{array}{l}\text { Coal is produced from the } \\
\text { accumulation of wood in the } \\
\text { ground. }\end{array}$ & $\begin{array}{l}\text { Coal comes from black stones resulting } \\
\text { from long burning. }\end{array}$ \\
\hline Question C & How to save fuel & By riding a private motorbike & $\begin{array}{l}\text { Because it is faster to get to the } \\
\text { destination and does not spend a lot of } \\
\text { fuel. }\end{array}$ \\
\hline Question D & Source of electrical energy & $\begin{array}{l}\text { The energy source that can be } \\
\text { utilized in the waterfall area is } \\
\text { wind power }\end{array}$ & $\begin{array}{l}\text { This energy source can be directly } \\
\text { flowed into people's homes and } \\
\text { converted into electrical energy. }\end{array}$ \\
\hline Question E & Energy Changes & $\begin{array}{l}\text { The form of energy change in the } \\
\text { lamp is electrical energy into light } \\
\text { energy only. }\end{array}$ & $\begin{array}{l}\text { When lit, the lamp converts heat energy } \\
\text { into energy }\end{array}$ \\
\hline Question F & $\begin{array}{l}\text { The process of changing the } \\
\text { form of energy sources }\end{array}$ & $\begin{array}{l}\text { The tool in hydropower that is } \\
\text { used to convert motion energy } \\
\text { into electrical energy is the flow of } \\
\text { water in rivers. }\end{array}$ & $\begin{array}{l}\text { The rushing water flows directly } \\
\text { produces electricity which is then } \\
\text { channeled to the windmill. }\end{array}$ \\
\hline
\end{tabular}

Based on table 2 the alternative concept of students' choices was wrong, but they believed that the choice was correct. In Figure 3, it is stated that students experience the most misconceptions in question $\mathrm{B}$. This question states to students that "Coal is an energy source that can be used as a power plant and fuel for vehicles. Coal is obtained from the process of...." Then almost all students who experience misconceptions believe that Coal is produced from the process of stockpiling wood in the ground, not from the mining process.

If students believe that coal is the result of hoarding wood, they will not realize that coal is a nonrenewable energy group because it comes from wood. 
This is supported by the results of research that proves that elementary school students experience a lot of misunderstandings about energy sources, especially about renewable and non-renewable energy sources (Boylan, 2008; Heron, Stefanel, \& Michelini, 2014).

With these findings, gathering information on students' alternative concepts and reasons is very important to know their conceptions. The causes of misconceptions in students can vary, including the condition of students when they receive learning that affects the understanding of concepts that they will receive later, students' experiences in interacting with the environment, the way teachers or educators teach, and selection of learning methods, and books or references (Astiti et al., 2020).

Researchers have conducted studies of learning difficulties and misconceptions on various topics, both at the elementary, middle and college levels, like a misconception on the topic of biology (Fisher \& Moody, 2002; Kumandaş, Ateskan, \& Lane, 2019), misconceptions of high school students about renewable energy resources and applications (Said Tortop, 2012), and misconception in chemistry topics (Shidiq, Yamtinah, \& Masykuri, 2019; Tüysüz, 2009). The methods used by researchers to identify and deal with misconceptions also vary, such as identifying students' misconceptions with the Two-tier multiplechoice instrument (Adodo, 2013; Bayrak, 2013; Chandrasegaran, Treagust, \& Mocerino, 2007; Lin, 2004; Othman, Treagust, \& Chandrasegaran, 2008; K.-C. D. Tan, Taber, Goh, \& Chia, 2005; K. C. D. Tan, Goh, Chia, \& Treagust, 2002; Treagust, 2012; Tüysüz, 2009), problem solving instrument (Reigosa \& JiménezAleixandre, 2007), and multiple choice instrument (Othman et al., 2008). Meanwhile, addressing the students misconception can be done by changing the concept (Atasoy, Akkus, \& Kadayifci, 2009), interview (Kirkwood \& Symington, 2009), and modeling (Shin, Espin, Deno, \& McConnell, 2009).

The explanation above shows that there have been many ways that researchers have done to identify misconceptions in various topics and levels of education. This research positioned a way to identify misconceptions in students with a four-tier instrument. A four-tier diagnostic instrument is one of the promising ways to identify students' misconceptions. This instrument can be applied to other science concepts, as well as at other levels of education. However, the identification and analysis of students' misconceptions require a follow-up from the teacher. Knowing students' misconceptions is not enough; further action needs to be followed to address students' conceptions. This study recommends further research to address students' conceptions. It is hoped that this finding can become a reference for teachers to identify misconceptions with the four-tier instrument.

\section{Conclusion}

The physical environment provides each student with experiences and shapes their initial conception of nature. Some of these initial conceptions are close to scientific concepts, some of which cause misconceptions in students. Teachers need a way to detect students' initial conceptions to provide the proper treatment to address students' misconceptions. The four-tier diagnostic test is one of the tools used to analyze students' conceptions. Based on the results of the analysis, most students experienced misconceptions on each item about the concept of energy. Students choose the wrong answer related to the concept of energy and believe that their answer is correct. In addition to knowing the level of students' conceptions, the use of four-tier diagnostic tests can also detect alternative concepts chosen by students in answering problems. The results of this study cannot be generalized widely regarding the initial concept of elementary school students about energy because the research participants are still limited. However, this research is expected to contribute theoretically and practically to how to analyze students' conceptual levels and how to describe alternative concepts for elementary school students about energy.

\section{References}

Adodo, S. O. (2013). Effects of Two-Tier Multiple Choice Diagnostic Assessment Items on Students' Learning Outcome in Basic Science Technology (BST). Academic Journal of Interdisciplinary Studies, 2(2), 201-210. https://doi.org/10.5901/ajis.2013.v2n2p201

Alwan, A. A. (2011). Misconception of Heat and Temperature Among Physics Students. Procedia Social and Behavioral Sciences, 12, 600-614. https://doi.org/10.1016/j.sbspro.2011.02.074

Amin, N., Wiendartun, \& Samsudin, A. (2016). Analisis Instrumen Tes Diagnostik Dynamic-Fluid Conceptual Change Inventory (DFCCI) Bentuk Four-Tier Test pada Beberapa SMA di Bandung Raya. Prosiding SNIPS 2016, 1(1), 570-574.

Astiti, D. T., Ibrahim, M., \& Hariyono, E. (2020). Application of POE (Predict-Observe-Explain) Learning Strategies to Reduce Students' Misconceptions in Science Subjects in Elementary School. International Journal of Innovative Science and Research Technology, 5(7), 437-445. https://doi.org/10.38124/ijisrt20jul478

Atasoy, B., Akkus, H., \& Kadayifci, H. (2009). The effect 
of a conceptual change approach on understanding of students' chemical equilibrium concepts. Research in Science and Technological Education, 27(3), 267-282. https://doi.org/10.1080/02635140903162587

Baryam, C., Samsudin, A., Suhandi, A., Rusdiana, D., \& Kaniawati, I. (2017). Promoting Conceptual Understanding on Magnetic Field Concept Through Interactive Conceptual Instruction (ICI) with PDEODEE Tasks. Turkish Online Journal of Educational Technology, 23(2), 1205-1210. Retrieved from:

https:/ / avesis.yildiz.edu.tr/yayin/00a0c34a0ca3-4c92-9564-b34c2d491a55/...pdeodee-tasks

Bayrak, B. K. (2013). Using Two-Tier Test to Identify Primary Students ' Conceptual Understanding and Alternative Conceptions in Acid Base. Mevlana Internationa Journal of Education, 3(2), 1926. https://doi.org/10.13054/mije.13.21.3.2

Bayuni, T. C., Sopandi, W., \& Sujana, A. (2018). Identification misconception of primary school teacher education students in changes of matters using a five-tier diagnostic test. Journal of Physics: Conference Series,

https://doi.org/10.1088/17426596/1013/1/012086

Boylan, C. (2008). Exploring elementary students' understanding of energy and climate change. International Electronic Journal of Elementary Education, 1(1), 1-15.

Caleon, I. S., \& Subramaniam, R. (2010). Do Students Know What They Know and What They Don't Know? Using a Four-Tier Diagnostic Test to Assess the Nature of Students' Alternative Conceptions. Research in Science Education, 40(3), 313-337. https://doi.org/10.1007/s11165-0099122-4

Cepni, S. (2009). Effects of Computer Supported Instructional Material (CSIM) in Removing Students Misconceptions about Concepts: Light, LightSource and Seeing. Energy Education Science and Technology Part B: Social and Educational Studies, 1(2), 51-83.

Chandrasegaran, a. L., Treagust, D. F., \& Mocerino, M. (2007). The development of a two-tier multiplechoice diagnostic instrument for evaluating secondary school students' ability to describe and explain chemical reactions using multiple levels of representation. Chemistry Education Research and Practice, 8(3), 293. https://doi.org/10.1039/b7rp90006f

Fisher, K., \& Moody, D. (2002). Student misconceptions in biology. Mapping Biology Knowledge, 55-75.

Fuadi, F. N., Sopandi, W., \& Sujana, A. (2021). The Mastery of Grade 4 of Elementary School
Students' Concepts on Energy Through the Implementation of the RADEC Learning Model. Journal of Physics: Conference Series, 1806(1), 1-8. https://doi.org/10.1088/1742-

6596/1806/1/012140

Gomez-Zwiep, S. (2008). Elementary teachers' understanding of students' science misconceptions: Implications for practice and teacher education. Journal of Science Teacher Education, 19(5), 437-454. https://doi.org/10.1007/s10972-008-9102-y

Gurel, D. K., Eryilmaz, A., \& McDermott, L. C. (2015). A Review and Comparison of Diagnostic Instruments to Identify Students' Misconceptions in Science. Eurasia Journal of Mathematics, Science and Technology Education, 11(5), 989-1008. https://doi.org/10.12973/eurasia.2015.1369a

Gurel, D. K., Eryilmaz, A., \& McDermott, L. C. (2017). Development and Application of A Four-tier Test to Assess Pre-service Physics Teachers' Misconceptions About Geometrical Optics. Research in Science and Technological Education, 35(2), $1-23$. https://doi.org/10.1080/02635143.2017.1310094

Hasyim, W., Suwono, H., \& Susilo, H. (2018). Three-tier Test to Identify Students' Misconception of Human Reproduction System. Jurnal Pendidikan Sains, 6(2), 48-54.

Hermita, N., Suhandi, A., Syaodih, E., Samsudin, A., Isjoni, Johan, H., ... Safitri, D. (2017). Constructing and Implementing a Four Tier Test about Static Electricity to Diagnose Pre-service Elementary School Teacher' Misconceptions. Journal of Physics: Conference Series, 895(1). https://doi.org/10.1088/17426596/895/1/012167

Heron, P., Stefanel, A., \& Michelini, M. (2014). Teaching and learning the concept of energy in primary school. Research Gate, 1-14. Retrieved from https://www.researchgate.net/publication/2284 63093_Teaching_and_learning_the_concept_of_en ergy_in_primary_school

Karpudewan, M., Ahmad, A. N., \& Chandrasegaran, A. L. (2017). Overcoming Students' Misconceptions in Science: Strategies and Perspectives from Malaysia. Overcoming Students' Misconceptions in Science: Strategies and Perspectives from Malaysia, 1344. https://doi.org/10.1007/978-981-10-3437-4

Kirkwood, V., \& Symington, D. (2009). Lecturer Perceptions of Student Difficulties in a First-Year Chemistry Course. Journal of Chemical Education. https://doi.org/10.1021/ed073p339

Kumandaş, B., Ateskan, A., \& Lane, J. (2019). Misconceptions in biology: a meta-synthesis study of research, 2000-2014. Journal of Biological 
Education,

53(4),

350-364.

https://doi.org/10.1080/00219266.2018.1490798

Laeli, C. M. H., Gunarhadi, \& Muzzazinah. (2020). Misconception of Science Learning in Primary School Students. Advances in Social Science, Education and Humanities Research, 397(Icliqe 2019), 657-671.

https://doi.org/10.2991/assehr.k.200129.083

Lin, S. W. (2004). Development and application of a two-tier diagnostic test for high school students' understanding of flowering plant growth and development. International Journal of Science and Mathematics Education, 2(2), 175-199. https:// doi.org/10.1007/s10763-004-6484-y

Millar, R. (2005). Teaching about energy Teaching about energy Teaching about energy, 4539(2003), 1-21.

Moon, A., Zotos, E., Finkenstaedt-Quinn, S., Gere, A. R., \& Shultz, G. (2018). Investigation of the role of writing-to-learn in promoting student understanding of light-matter interactions. Chemistry Education Research and Practice, 19(3), 807-818. https://doi.org/10.1039/c8rp00090e

Othman, J., Treagust, D. F., \& Chandrasegaran, A. L. (2008). An investigation into the relationship between students' conceptions of the particulate nature of matter and their understanding of chemical bonding. International Journal of Science Education, 30(11), 1531-1550. https://doi.org/10.1080/09500690701459897

Pine, K., Messer, D., \& John, K. (2001). Children's Misconceptions in Primary Science: A Survey of Teachers' Views. Research in Science $\mathcal{E}$ Technological Education, 19(1), 79-96. https://doi.org/10.1080/0263514012004624 0

Reigosa, C., \& Jiménez-Aleixandre, M. P. (2007). Scaffolded problem-solving in the physics and chemistry laboratory: Difficulties hindering students' assumption of responsibility. International Journal of Science Education, 29(3), 307329. https://doi.org/10.1080/09500690600702454

Rohmanasari, F., \& Ermawati, F. U. (2020). Using FourTier Multiple Choice Diagnostic Test to Identify Misconception Profile of 12th Grade Students in Optical Instrument Concepts. Journal of Physics: Conference Series, 1491(1), 1-8. https:// doi.org/10.1088/17426596/1491/1/012011

Said Tortop, H. (2012). Awareness and misconceptions of high school students about renewable energy resources and applications: Turkey case. Energy Education Science and Technology Part B: Social and Educational Studies, 4(3), 1829-1840.

Shidiq, A. S., Masykuri, M., \& Susanti, E. (2014). Pengembangan Instrumen Penilaian Two-Tier
Multiple Choice Untuk Mengukur Keterampilan Berpikir Tingkat Tinggi (Higher Order Thinking Skills ) Pada Materi Kelarutan Dan Hasil Kali Kelarutan Untuk Siswa Sma / Ma Kelas Xi. Jurnal Pendidikan Kimia, 3(4), 83-92. Retrieved from: https://jurnal.fkip.uns.ac.id/index.php/kimia/ar ticle/view/4507 [Indonesian]

Shidiq, A. S., Masykuri, M., \& Susanti, E. (2015). Analisis Higher Order Thinking Skills (HOTS) Menggunakan Instrumen Two-Tier Multiple Choice Pada Materi Kelarutan Dan Hasil Kali Kelarutan Untuk Siswa Kelas Xi Sma N 1 Surakarta. Prosiding Seminar Nasional Pendidikan Sains, (November), 2015-2159. [Indonesian]

Shidiq, A. S., \& Yamtinah, S. (2019). Pre-service chemistry teachers' attitudes and attributes toward the twenty-first century skills. Journal of Physics: Conference Series, 1157(4), 042014. https://doi.org/10.1088/17426596/1157/4/042014

Shidiq, A. S., Yamtinah, S., \& Masykuri, M. (2019). Identifying and addressing students' learning difficulties in hydrolysis using testlet instrument. AIP Conference Proceedings, 2194(020117), 1-8. https://doi.org/10.1063/1.5139849

Shin, J., Espin, C. A., Deno, S. L., \& McConnell, S. (2009). Use of hierarchical linear modeling and curriculum-based measurement for assessing academic growth and instructional factors for students with learning difficulties. Asia Pacific Education Review, 5(2), 136-148. https://doi.org/10.1007/bf03024951

Soeharto, Csapó, B., Sarimanah, E., Dewi, F. I., \& Sabri, T. (2019). A Review of Students' Common Misconceptions in Science and Their Diagnostic Assessment Tools. Jurnal Pendidikan IPA Indonesia, $8(2)$, 247-266. https://doi.org/10.15294/jpii.v8i2.18649

Soeharto, S. (2021). Development of A Diagnostic Assessment Test to Evaluate Science Misconceptions in Terms of School Grades: A Rasch Measurement Approach. Journal of Turkish Science Education, 18(3), 351-370.

Suparno, P. (2013). Miskonsepsi dan Perubahan Konsep dalam Pendidikan Fisika (Cet. 2). Jakarta: Grasindo.

Tan, K.-C. D., Taber, K. S., Goh, N.-K., \& Chia, L.-S. (2005). The ionisation energy diagnostic instrument: a two-tier multiple-choice instrument to determine high school students' understanding of ionisation energy. Chemistry Education Research $\begin{array}{lll}\text { and } \quad \text { Practice, } & 6(4),\end{array}$ https://doi.org/10.1039/b5rp90009C

Tan, K. C. D., Goh, N. K., Chia, L. S., \& Treagust, D. F. (2002). Development and application of a two-tier multiple choice diagnostic instrument to assess 
high school students' understanding of inorganic chemistry qualitative analysis. Journal of Research in Science Teaching, 39(4), 283-301. https://doi.org/10.1002/tea.10023

Treagust, D. (2012). Diagnostic assessment in science as a means to improving teaching, learning and retention. Australian Conference on Science, (1998), $1-9$.

Tüysüz, C. (2009). Development of two-tier diagnostic instrument and assess students' understanding in chemistry. Scientific Research and Essay, 4(6), 626631.

Wijayanti, M. D., Raharjo, S. B., Saputro, S., \& Mulyani, S. (2018). Investigation to reduce students' misconception in energy material. Journal of Physics: Conference Series, 1013(1), 1-8. https://doi.org/10.1088/17426596/1013/1/012080

Yamtinah, S., Indriyanti, N. Y., Saputro, S., Mulyani, S., Ulfa, M., Mahardiani, L., ... Shidiq, A. S. (2019). The identification and analysis of students' misconception in chemical equilibrium using computerized two-tier multiple-choice instrument. Journal of Physics: Conference Series, 1157(4). $\quad$ https://doi.org/10.1088/17426596/1157/4/042015

Yang, D. C., \& Lin, Y. C. (2015). Assessing 10- to 11year-old Children's Performance and Misconceptions in Number Sense Using a Fourtier Diagnostic Test. Educational Research, 57(4), 368-388.

https:// doi.org/10.1080/00131881.2015.1085235

Yuenyong, J., \& Yuenyong, C. (2021). Examining Grade 5 Students' Capability of Analytical Thinking in Learning about Heat Conduction Through Predict - Observe - Explain (POE) strategy. Journal of Physics: Conference Series, 1835(1), 1-9. https:// doi.org/10.1088/17426596/1835/1/012024 